\title{
Doctors, families and the industry in the clinic: the management of 'intersex' children in Swiss paediatric medicine (1945-1970)
}

\author{
Mirjam Janett ${ }^{1}$, Andrea Althaus ${ }^{1}$, Marion Hulverscheidt ${ }^{2}$, Rita Gobet ${ }^{3}$, Jürg Streuli ${ }^{4}$ and \\ Flurin Condrau ${ }^{1 \star}$ \\ ${ }^{1}$ History of Medicine, University of Zurich, Zurich, Switzerland \\ ${ }^{2}$ Modern History, University of Kassel, Kassel, Germany \\ ${ }^{3}$ Paediatric Urology, University Children's Hospital Zurich, Zurich, Switzerland \\ ${ }^{4}$ Paediatric Palliative Medicine, Children's Hospital of Eastern Switzerland, St. Gallen, Switzerland \\ ${ }^{*}$ Corresponding author. Email: flurin.condrau@uzh.ch
}

\begin{abstract}
This manuscript investigates clinical decisions and the management of 'intersex' children at the University Children's Hospital Zurich between 1945 and 1970. This was an era of rapid change in paediatric medicine, something that was mirrored in Zurich. Andrea Prader, the principal figure in this paper, started his career during the late 1940s and was instrumental in moving the hospital towards focusing more on expertise in chronic diseases. Starting in 1950, he helped the Zurich hospital to become the premier centre for the treatment of so-called 'intersex' children. It is this treatment, and, in particular, the clinical decision-making that is the centre of our article. This field of medicine was itself not stable. Rapid development of diagnostic tools led to the emergence of new diagnostic categories, the availability of new drugs changed the management of the children's bodies and an increased number of medical experts became involved in decision-making, a particular focus lay with the role of the children themselves and of course with their families. How involved were children or their families in an era widely known as the golden age of medicine?
\end{abstract}

Keywords: Paediatrics; 'Intersex'; Gender; Patient records; DSD

\section{Introduction}

In April 1959, Peter Mueller ${ }^{*},{ }^{1}$ wrote to Andrea Prader (1919-2001), a paediatric endocrinologist at the Children's Hospital Zurich (Kispi), requesting an appointment for his 7-year-old twin girls in the presence of Guido Fanconi (1892-1979), then medical director of the hospital. The girls had been looked after for 5 years by a Dr Ernst Philipp of the gynaecological hospital in the German city of Kiel. According to Mueller, Dr Philipp had mentioned to him that 'it is possible that the girls are more male than female'. ${ }^{2}$ Prader duly examined the family history, and the physical status of the twins - the psychological status was examined by a psychiatrist. According to the patient files, the clitoris of one of the twins - Sandra ${ }^{*}$ 'was enlarged', because 'it had grown constantly together with the child'. Lately, she even had erections. Her character was assessed to be more 'boyish' than that of her sister. According to the notes, Sandra* had recently asked her father whether he could make her into a boy. The files note that she 'never played with

\footnotetext{
${ }^{1}$ All patient or family names in the article have been anonymised. Medical staff names with a publication record have been left unchanged.

${ }^{2}$ Letter to Andrea Prader, 8 April 1959, patient record, Staatsarchiv Zürich (StAZH), Z 810.3804.

(C) The Author(s), 2021. Published by Cambridge University Press. This is an Open Access article, distributed under the terms of the Creative Commons Attribution-NonCommercial-ShareAlike licence (http://creativecommons.org/licenses/by-nc-sa/4.0/), which permits non-commercial re-use, distribution, and reproduction in any medium, provided the same Creative Commons licence is included and the original work is properly cited. The written permission of Cambridge University Press must be obtained for commercial re-use.
} 
dolls', but loved 'to play soccer, Indians and with rifles'. ${ }^{3}$ This brief episode demonstrates the changing field of the medical management of 'intersexual' ${ }^{4}$ children, their therapeutic orientation on social norms for sex determination and the arising problems in case of unclear sex, and it emphasises the various groups involved in the medical decision-making. Following on from the appointment with Prader, a long patient history developed for the twin girls, and at long last Prader advised that it was advisable to seek the virilisation of the girls, in other words, to raise them as boys rather than girls. We do not know whether this was carried out, since in this case, the patients had come to Zurich from Germany for a second opinion. But the story allows us to highlight our fundamental research question: How did clinicians such as Prader take their decisions in relation to the treatment of 'intersex' children? Who was involved in the management and/or treatment of the children? How varied was the management of this question during our period? We assume that, after the Second World War, medicine had already turned into a specialised entity, which would in turn result in Prader not being the only physician involved in the care of the children.

The field of 'intersex' medicine linked medical experts of various disciplines, institutions in more than one country, the families and of course their children. New diagnostic possibilities and the involvement of new disciplines such as the psychiatry or genetics in the decision-making process provided a new basis for the treatment of 'intersexuality'. The University Children's Hospital in Zurich, locally known as the Kispi (short for the German word Kinderspital), had become the premier centre for the treatment of so-called intersexual children in Europe. ${ }^{5}$ It was founded in 1874, positioned itself as a leading institution in Europe for newly detected chronic conditions. Its director until 1961, Guido Fanconi, helped to establish its reputation as a leading centre for scientific paediatric medicine. Max Grob was among the first paediatric surgeons in Switzerland - and author of the first German-language textbook for paediatric surgery. ${ }^{6}$ Under Fanconi, the Kispi developed its scientific laboratory infrastructure, which allowed the expansion of diagnostic and therapeutic research and practice in the hospital. These new tools allowed innovative investigations of previously unknown conditions. Fanconi's protégé and successor as the director of the Kispi until 1986 Andrea Prader pushed forward paediatric endocrinology as a founding member of the European Society for Paediatric Research as well as the European Society for Paediatric Endocrinology (founded 1961), the president of which he was in 1971. Prader enjoyed a high reputation and was well connected with physicians with the same research interests all over the world. ${ }^{7}$ The endocrinologist Gertrud Mürset (1924-2013), head of the outpatient clinic of the Kispi, was responsible for the outpatient care of patients after discharge from the hospital. They were part of a transnational network of specialists which consolidated new approaches to the treatment of 'intersexual' patients. A turning point for Prader's career was the Sixth International Paediatric Congress in Zurich in 1950. It was the first such congress after the Second World War and attracted well over 2000 physicians from over fifty-two nations. ${ }^{8}$ There he made the acquaintance of Lawson Wilkins from the Johns Hopkins University Hospital in Baltimore and developed a research interest in 'intersexuality'. Prader went on a

\footnotetext{
${ }^{3}$ Patient record, StAZH, Z 810.3804.

${ }^{4}$ Among activists, the problematic of using historical terms as 'intersex', 'hermaphrodites' or the German term 'Zwitter', which has historically a negative connotation, is discussed today. In medicine, they are using the term 'disorders of sexual development' (DSDs), which is also contested among activists, and an alternative medical term is divergences/differences of sexual development (DSDs). See Elizabeth Reis, 'Divergence or Disorder? The Politics of Naming Intersex', Perspectives in Biology and Medicine, 50 (2007), 535-43. In this article, we use the historical medical term 'intersexuality', even though the historical actors are often inconsistent in their terminology.

${ }^{5}$ The activist group 'Zwischengeschlecht' addressed an open letter to the Kispi, and the University of Zurich, requesting a historical investigation to find out the extent to which children had been succumbed to surgical interventions on their genitals, in particular in the form of clitorectomies at the Children's Hospital in Zurich. Our research project is the result of this movement, and we are indebted to the group for allowing us to pursue it.

${ }^{6}$ Andrea Prader became in 1962 first ordinarius for paediatrics, and Max Grob in 1957 Associate Professor for paediatric surgery at the University of Zurich. Grob was also the head of the surgical department of the Kispi from 1939 to 1971.

${ }^{7}$ Hans-Rudolf Wiedemann, 'Andrea Prader: On the Occasion of His 65th Birthday', European Journal of Paediatrics, 143 (1984), 80-1.

${ }^{8}$ Program of the Sixth International Congress of Paediatrics, Annual Report Children's Hospital Zurich, 1950, 7, Stadtarchiv Zürich (StARZH), V.L.105.
} 
return visit and stayed for a year at the Bellevue Hospital in New York with L.E. Holt Jr. He also visited the Johns Hopkins Hospital in Baltimore to work with Lawson Wilkins. ${ }^{9}$ Prader's career allowed the Kispi to be turned into the leading institution in Europe for the treatment of children with 'intersexual' bodies.

Our project is based on a substantial historical archive of patient records from the Kispi. ${ }^{10}$ We draw on a collection of 190 clinical patient records from the years of 1945-1970 to provide evidence for our research. ${ }^{11}$ This period covers Prader's emergence as the leading European paediatric endocrinologist as well as the advent of new laboratory premises and the incorporation of new hormonal and genetic knowledge into clinical practice. Clinical records are hybrid sources: They mirror the clinical gaze, but often also include letters, postcards or drawings by patients or their families, highlighting the interaction of doctors, patients and technologies. ${ }^{12}$ On the basis of the hospital's annual reports, and using a list of historic diagnostic categories, we identified 265 medical cases matching a historical form of 'intersex'. Our selection of 190 patients had been treated (often more than once) for such conditions in Zurich. The majority of children who came to the hospital suffered from 'Congenital Adrenogenital Hyperplasia' (CAH; 55 of 190 patients). Further syndromes were 'Hermaphroditism', 'Pseudohermaphroditism' or 'Klinefelter'. A further complication is the fact that a substantial proportion of patients (thirty-eight patients) did not attend the hospital because of an entry diagnosis. The case was then only detected while already at hospital. Such a collection is never complete, but we are convinced that our cases are varied and substantial enough to provide a sound basis for our investigation.

The field of historical 'intersex' research has developed substantially in recent years, and it has been a 'living discourse', where activists, political interests and contemporary understandings of DSD interact and sometimes clash with historical understandings of the issues. Historical research has focused on the medical treatment of 'intersex' from the end of the nineteenth century until the 1950s, often based on printed sources. 'Hermaphroditism' (an older term for 'intersex') was increasingly medicalised in the late nineteenth century, as scientific interest in sex research began to increase. Historiography has pointed out how the determination of the 'true sex' shifted in the first half of the twentieth century from a gonadal focus to a psychological one. This partly explains the increasing influence of surgery in the field. ${ }^{13}$ In the U.S. context, the treatment of 'intersex' children began to implement John Money's psychological theory of gender acquisition. ${ }^{14}$ Wilkins was convinced that a child could learn the appropriate gender role so long as the genitals fit the chosen gender. ${ }^{15}$ The notion of changeability of gender identity resulted in the so-called Hopkins protocols which recommended that the child's sex should not be changed after 18-24 months of age. Therefore, they recommended early genital surgery to adjust children's genitals,

\footnotetext{
${ }^{9}$ See Sandra Eder, 'Gender and Cortisone. Clinical Practice and Transatlantic Exchange in the Medical Management of Intersex in the 1950s', Bulletin of the History of Medicine, 92 (2018), 604-33.

${ }^{10} \mathrm{Health}$ records and access to them is governed at the level of Canton. Zurich's archival law stems from 2014 and contains a section on patient notes. The State Archive of Zurich house all remaining records of the Kispi, which - for our period - amount to around 25 per cent of all patients ever treated there. The years of 1950, 1955, 1960 and 1965 have been archived fully, which allowed us to double-check that we did not miss cases on a systematic basis.

${ }^{11}$ Verfügung der Gesundheitsdirektion des Kantons Zürich, September 2017.

${ }^{12}$ For science as a practice, see Ian Hacking, The Social Construction of What? (Cambridge, MA: Harvard University Press, 1999), 98; Ilona Löwy, 'The Strength of Weak Concepts - Boundary Concepts, Federative Experimental Strategies and Disciplinary Growth: The Case of Immunology', History of Science, 30, 4 (1992), 371-96; Dominique Pestre, 'Pour une histoire sociale et culturelle des sciences: Nouvelles définitions, nouveaux objets, nouvelles pratiques', Annales: Histoire, Sciences Sociales, 50, 3 (1995), 487-522 and Andrew Pickering, Science as Practice and Culture (Chicago: University of Chicago Press, 1992).

${ }^{13}$ Alice Dreger, Hermaphrodites and the Medical Invention of Sex (Cambridge: Harvard University Press, 1998), 29. Also see Sandra Eder, 'The Volatility of Sex: Intersexuality, Gender and Clinical Practice in the 1950s', Gender \& History, 22 (2010), 692-707, 693; Ulrike Klöppel, XXOXY ungelöst: Hermaphroditismus, Sex und Gender in der deutschen Medizin. Eine historische Studie zur Intersexualität (Bielefeld: transcript Verlag, 2010), 257-9; Anne Fausto-Sterling, Sexing the Body: Gender Politics and the Construction of Sexuality (New York: Basic Books, 2000), 40 and Alison Redick, 'American History XY: The Medical Treatment of Intersex, 1916-1955’ (unpublished PhD thesis: New York University, 2004), 13.

${ }^{14}$ Redick, ibid., 13.

${ }^{15}$ For a broader discussion of John Money's concept of gender role, see Eder, op. cit. (note 13), 693. Further conceptual developments in the 1960s linked to psychiatrist and psychoanalyst Robert Stoller feature prominently in Klöppel, op. cit. (note 13), 499-503.
} 
the assigned sex in order to facilitate the growing up of the child. ${ }^{16}$ While these considerations were known to Prader, his clinical practice turned out to be influenced but not determined by Hopkins. ${ }^{17}$ Not much attention has been paid yet to the decision-making process in the clinic. Historiography has demonstrated how medicine evolved throughout the nineteenth century. ${ }^{18}$ In particular, analyses of the "profession of medicine" have highlighted how medical doctors gained dominance in the medical marketplace. ${ }^{19}$ In the clinical care of patients, researchers argued for the silencing of the patient, which implied medical decision-making without much influence on the part of the patient. ${ }^{20}$ Recent studies, however, have begun to point to a more nuanced way of understanding the era of paternalistic medicine. $^{21}$

First, we investigate the dynamic field of 'intersex' medicine, with a particular emphasis on new diagnostic tools and hormone-based therapy methods. In particular, cortisone, launched in 1949, reinforced the 'underlying assumptions about the body's physical nature', with a clear female or male sex for children with CAH. ${ }^{22}$ With cortisone, the practice of treating intersex as a 'medical emergency ${ }^{23}$ was extended to all intersex conditions. ${ }^{24}$ The emergence of cortisone-based treatment led the pharmaceutical industry become a powerful actor in the clinical management of 'intersex'. Second, we show how changing technologies like the chromosomal technique introduced a new logic - which had an effect on therapeutic processes but also fundamentally changed the notion of sex. Children who had previously not been considered 'intersex' came now to the fore. Third, we will analyse how changing practices in the management of 'intersex' affected the relationships between parents, physicians and children, as well as to new communication strategies of the doctors involved. Fourth, we analyse how decisions about sex determination, therapeutic interventions and surgical treatments came about. We ask who was involved in such decisions, and what influence families or doctors had in the process. This took place at a time when - to the best of our knowledge - there were no binding regulatory guidelines in Switzerland regarding the consent of patients to receive a therapy or, in fact, for being part of experimental treatment or research projects. ${ }^{25}$

\section{Cortisone and the pharmaceutical industry in the clinic}

Recent research has set out the entanglement between the industry and the clinic which facilitated a 'transatlantic circulation of the knowledge' between paediatric endocrinologists Lawson Wilkins in the

\footnotetext{
${ }^{16}$ Eder, op. cit. (note 13).

${ }^{17}$ Eder, op. cit. (note 9).

${ }^{18}$ Charles E. Rosenberg, 'The Therapeutic Revolution: Medicine, Meaning and Social Change in Nineteenth-Century America', Perspectives in Biology and Medicine, 20 (1977), 485-506.

${ }^{19}$ Eliot Freidson, Profession of Medicine. A Study of the Sociology of Applied Knowledge (New York, Dodd City and Mead: Harper and Row, 1970) and Rudolf Braun, 'Zur Professionalisierung des Ärztestandes in der Schweiz', in W. Conze and J. Kocka (eds), Bildungsbürgertum im 19. Jahrhundert, Teil 1: Bildungssystem und Professionalisierung in internationalen Vergleichen (Stuttgart: Klett-Cotta, 1985), 332-57.

${ }^{20}$ Nicholas C. Jewson, 'The Disappearance of the Sick-Man from Medical Cosmology, 1770-1870', Sociology, 10 (1976), 22544 and Mary E. Fissell, 'The Disappearance of the Patient's Narrative and the Invention of Hospital Medicine', in A. Wear and R. French (eds), British Medicine in an Age of Reform (London: Routledge, 1991), 92-109.

${ }^{21}$ Karen Nolte, 'Zeitalter des ärztlichen Paternalismus? - Überlegungen zu Aufklärung und Einwilligung von Patienten im 19. Jahrhundert', Medizin, Gesellschaft und Geschichte 26 (2006), 59-89 and Valérie Leclercq, 'Langue de bois et vérités divines: pratiques de l'information à l'ère du paternalisme médical, Bruxelles, 1870-1930', Gesnerus, 73 (2016), 123-47.

${ }^{22}$ Fausto-Sterling, op. cit. (note 13), 7.

${ }^{23}$ Redick, op. cit. (note 13), X.

${ }^{24}$ Sandra Eder, 'The Birth of Gender: Clinical Encounters in the Treatment of Hermaphroditic Children at Johns Hopkins (1940-1956)' (unpublished PhD thesis: Johns Hopkins University Baltimore, 2011).

${ }^{25}$ The Swiss Academy of Medical Sciences (SAMW) published in 1970 the first guidelines for clinical research in Switzerland. But they were not codified under Swiss cantonal law. In Zurich, this changed in 1971, when the SAMW guidelines were made legally binding. Schweizerische Akademie der medizinischen Wissenschaften (ed.), Richtlinien für Forschungsuntersuchungen am Menschen (Basel: Schwabe, 1970). Verordnung über die kantonalen Krankenhäuser (1971.03.25), StAZH, OS 44.
} 
United States and Prader in Europe. ${ }^{26}$ The new 'miracle drug', as Prader considered it, contributed to new therapeutic approaches which turned children into patients with a chronic condition. But what was the role of industry and its products in the clinical decision-making process? We will argue that the influence of industry not only showed in the supply of certain drugs, but also in a new foundation of medical knowledge.

In 1949, the synthetic corticosteroid cortisone came onto the market. ${ }^{27}$ First applied against rheumatoid arthritis, it soon became evident that it helped against a set of unspecific diseases. However, cortisone did not address the causes of illness but suppressed their symptoms, and as such emphasised the long-term management of chronic diseases. ${ }^{28}$ One year after its launch, Wilkins in Baltimore applied cortisone to suppress virilisation in $\mathrm{CAH} .{ }^{29}$ This syndrome was understood as an excess of androgens secreted by the adrenal gland. It affected female as well as male children, and, in some cases, the adrenal pathology caused a life-threatening salt loss. The excess of androgens resulted in 'a masculinisation' of the affected children. ${ }^{30}$ In boys, it caused developmental problems, such as precocity, and in girls, it caused, among other things, increased hair growth and an enlarged clitoris. ${ }^{31}$ Although this syndrome was rare and had 'little publicity or national health significance', the medical developments and discoveries made at the Baltimore Paediatric Endocrinology Clinic have been considered pivotal to the subsequent consolidation and standardisation of intersex case management'. ${ }^{32}$ Prader, as 'a former student of Wilkins' (Prader in 1975) opined that the Kispi in Zurich 'probably (had) the most experience in Europe in this field'. ${ }^{33}$ However, what appears in retrospect as 'a consistent treatment regime' was, in fact, far more 'messy, pragmatic and contingent', as Eder emphasises. ${ }^{34}$ The paediatric textbook of Guido Fanconi and Arvid Wallgren allows to trace this process. ${ }^{35}$ As a reference for paediatric medicine, it appeared in nine editions between 1950 and 1972 and was translated several times. The third edition of 1954 recommended for the first time a long-term treatment with cortisone' as a therapy for $\mathrm{CAH}$, while acknowledging that it had 'not been yet well researched'. ${ }^{36}$ In 1961, however, 'the long-term treating with cortisone' was now described as 'the therapy of choice' in the textbook. ${ }^{37}$

These insights reposed on clinical trials with cortisone conducted by Prader. Prader mobilised for his trials the pharmaceutical industry as a powerful ally. The clinical trials after the war had aimed to settle debate within medical circles. But research and therapeutic endeavour were increasingly intertwined. The Swiss pharma company Ciba distributed cortisone in Switzerland, which it imported from the

\footnotetext{
${ }^{26}$ Eder, op. cit. (note 9), 604.

${ }^{27}$ Andrea Prader, 'Endokrinologie', 100 Jahre Kinderspital Zürich 1874-1974 (Zurich: Kinderspital Zürich, 1974), 117-20 (here 117).

${ }^{28}$ Lea Haller, Cortison: Geschichte eines Hormons, 1900-1955 (Interferenzen 18, published PhD thesis: Eidgenössische Technische Hochschule ETH Zürich, 2012), 13.

${ }^{29}$ Lawson Wilkins et al., 'Treatment of Congenital Adrenal Hyperplasia with Cortisone', The Journal of Clinical Endocrinology, 11, 1 (1951), 1-25. For Wilkins discovery, see Redick, op. cit. (note 13), 13 and Eder, op. cit. (note 13).

${ }^{30} \mathrm{G}$. Fanconi and A. Wallgren (eds), Lehrbuch der Pädiatrie, 2nd edn (Basel: Benno Schwabe \& Co. Verlag, 1952), 260.

${ }^{31}$ Lawson Wilkins, 'The Diagnosis of the Adrenogenital Syndrome and Its Treatment with Cortisone', The Journal of Pediatrics, 41, 6 (1952), 860-74. In the case files, there are a lot of photographs with naked children and their genitals. Whereas early photographs do not cover their faces, since the 1960s, the faces have often been blacked out. To not reproduce this clinical gaze on genitals, we have not published these pictures. Research shows that these photographs were traumatic for a lot of children. They felt displayed and this prompted negative emotions such as shame and helplessness.

${ }^{32}$ Eder, op. cit. (note 9), 607.

${ }^{33}$ Letter from Andrea Prader to the director of the department of education of the Cantone of Zurich regarding paid leave for congress participation in Baltimore, 18 July 1975, UZH, E.3.1050, Prader_1975, Gesuch Kongressurlaub.

${ }^{34}$ Eder, op. cit. (note 9), 608.

${ }^{35}$ G. Fanconi and A. Wallgren (eds), Lehrbuch der Pädiatrie, 3rd edn (Basel: Benno Schwabe \& Co. Verlag, 1954).

${ }^{36}$ Ibid., 287. They mentioned the diagnosis 'CAH' in the second edition in 1952 for the first time and noted that this new diagnosis would correspond to the former 'pseudopubertas internalis'.

${ }^{37}$ G. Fanconi and A. Wallgren (eds), Lehrbuch der Pädiatrie, 6th edn (Basel: Benno Schwabe \& Co. Verlag, 1961).
} 
U.S. division of Merck. ${ }^{38}$ Ciba had already played a leading role in steroid research. ${ }^{39}$ During the 1950s, the new drug was still a scarce and expensive commodity even though the physicians supported by pharma pinned their hopes on it.

Prader treated the first patient with the diagnosis of 'Pseudohermaphroditism' with the new 'miraculous' drug within a year after the drug's launch. ${ }^{40}$ Wilkins, who was attending the Paediatric Congress in Zurich, saw an infant patient at the Kispi at the request of Prader, where the diagnosis remained unclear. Later, they recognised that the child was suffering of Congenital Adrenogenital Hyperplasia (CAH) with adrenal insufficiency. ${ }^{41}$ Already 'successfully' treated with salt and the drug Percorten (a synthetic adrenocorticosteroid, launched in 1939 by Ciba), Wilkins proposed cortisone for further treatment. ${ }^{42}$ Previously, the therapeutic options for CAH had been limited: There were trials with various hormonal treatments. Surgeons tried to stop virilisation with the removal of the adrenal gland, a highly invasive intervention. ${ }^{43}$ Although such interventions could occasionally stop the premature growth of pubic hair in some female patients, the treatment success was temporary. ${ }^{44}$

In 1951, having come back from the United States, Prader prescribed cortisone to a 6-year-old boy, Martin*, although neither Prader nor Fanconi was sure about the correct diagnosis nor dosage. The boy had been presented, because his penis was the size of that 'of an adolescent'. ${ }^{45}$ Prader informed the referring general practitioner (GP) that a clear diagnosis would be very difficult: The 'size of his genitals' seemed to 'indicate precocious puberty'. But because of the 'small size of the testicles', it could just as easily be a case of CAH. He suggested 'a long-term therapy [of cortisone] in small doses' would be necessary, underlining that after his research work with Wilkins, he was convinced of the 'extraordinary success' of cortisone regarding 'the suppression of androgens'. ${ }^{46}$ The physicians involved based their decision not on a secure diagnosis, but on the possible effect of the compound on the child's genitals. This story confirms that in the therapy with cortisone, the goal was to maintain a 'normal' physical appearance as much as possible and to normalise the child's body.

Prader's first longer running cortisone trial in the early fifties was supported by the pharmaceutical companies Ciba and Merck. They supplied Prader with the drug, and Ciba covered the publication fees. The aim of the study was to investigate the necessary duration of treatment with cortisone. ${ }^{47}$ It became evident that therapeutic success was only achievable with long-term-treatment. By stopping the cortisone, the unwanted virilisation would reappear. The clinical trials with children suffering CAH provided evidence for such effects. However, knowledge about effects and effectiveness of the drug

\footnotetext{
${ }^{38}$ Ciba just produced a small amount of cortisone itself, and they decided to import cortisone in bulk from Merck. See Haller, op. cit. (note 28), 230.

${ }^{39}$ In 1936, Ciba synthesised testosterone for the first time and launched it under the name 'Perandren'. In clinical practice, this drug was used for development disorders of male sexual organs. Rapport, Allgemeines Firmenarchiv Novartis - CibaArchiv (Ciba), FO 10.00, Pharma: Forschung, Biologische Zweckforschung. At the Kispi, they treated children with Klinefelter's syndrome with Perandren.

${ }^{40}$ The circulation of this 'biomedical knowledge' is analysed in detail by Sandra Eder. See Eder, op. cit. (note 9).

${ }^{41}$ Patient record, StAZH, Z 810.3833.

${ }^{42}$ See Andrea Prader, 'Pseudohermaphroditismus femininus mit kongenitaler Nebennierenrinden-Insuffizizienz', special print, originally published in Helvetica Paediatrica Acta, 5 (1950), 426-33.

${ }^{43}$ The Surgeon Hugh Young in Baltimore described in his autobiography the removal of the adrenal gland by female 'hermaphrodites'. Hugh Hampton Young, Hugh Young: A Surgeon's Autobiography (New York: Brace, 1940), 206. See Redick, op. cit. (note 13), 154.

${ }^{44}$ In 1957, the Head of the Surgery Department of the Kispi, Max Grob, dissuaded from this treatment and considered cortisone treatment as the therapy of choice. See Max Grob, Lehrbuch der Kinderchirurgie (Stuttgart: Georg Thieme Verlag, 1957), 586. In our sample, we have seven removals of the adrenal gland between 1922 and 1949. Patient records, StAZH, Z $810.3487 ; 810.3496 ; 810.3516 ; 810.3519 ; 810.3520 ; 810.3750$ and 810.3826 . After the launch of cortisone, there is no evidence in the patient records for such surgeries.

${ }^{45}$ Patient record, StAZH, Z 810.3498.

${ }^{46}$ Letter from Andrea Prader to the GP, 16 December 1951, patient record, StAZH, Z 810.3498.

${ }^{47}$ Andrea Prader, 'Die Cortisondauerbehandlung des adrenogenitalen Syndroms', Helvetica Paediatrica Acta, 8 (1953), $386-423$.
} 
remained scarce. Prader's notes in the files confirm this, when he mentions that he 'injected' today '200mg of cortisone'. It should 'theoretically' last for ' 3 weeks'. ${ }^{48}$ In another record, he noted that 'an attempt should be made' with the Ciba sample. ${ }^{49} \mathrm{He}$ informed the mother of a patient that 'in case of an overdosage (...), the therapy had to be stopped' ${ }^{50}$ The early application of cortisone in clinical practice was not yet based on full knowledge concerning dosage, side effects or length of prescription, nor in effectiveness. Historiography has pointed out that 'the clinical contribution to endocrine discourse' was increasingly relevant. ${ }^{51}$ But the paediatric introduction of cortisone did not differ much from other areas in medicine, where newly available drugs were introduced on an experimental level without any regulatory obstacles. ${ }^{52}$

The fact that industry collaborated with Prader shows the importance of the Kispi as a paediatric clinic. Ciba's internal guidelines for clinical research considered it necessary 'for a quick trial' that the 'tester' has the 'necessary know-how and suitable medical supplies'. Furthermore, testers should 'be located in Switzerland or in a country where the control over the investigation and an interference of the further course' were possible. The 'steering of the trial' would be of upmost importance in order not to have to cancel it because of 'an inadequate conduct' and/or a 'wrong interpretation of the compound'. ${ }^{53}$ With its international reputation, Prader's expertise in disorders of the adrenal gland and the possibility of Prader providing a sufficient sample of testers, the Kispi fulfilled all these criteria.

Ciba worked closely with the hospital. They provided Prader with free samples of cortisone not only for trials but also for his general therapeutic purposes. ${ }^{54}$ It seems that the supply of cortisone influenced treatment decisions. In 1951, for example, Prader informed the GP of Martin* that Fanconi and he had decided 'to make an attempt with cortisone, $75 \mathrm{mg}$ every 4 days'. They would hope to 'get cortisone from Ciba for free (...), a long-term therapy that is currently still too expensive'.$^{55}$ In return, Prader reported information about impact, effects and applied dosages of the medication. If Prader showed a scientific interested in a 'case' which was either not covered by health insurance or too expensive for the parents, he had access to an emergency fund to pay for the treatment. ${ }^{56}$ Sometimes he dispensed the required drug for free for years. For example, in 1963, he informed the mother of a former patient that he could not deliver her any more drugs, as the Kispi administration had realised that the patient was no longer a child. ${ }^{57}$

Ciba and the Kispi not only shared 'knowledge, and data on cortisone therapy', ${ }^{58}$ but also started a full research collaboration. In addition to supplying drugs, the company financed Prader's research endeavours. In 1958, Ciba paid the salary of a resident physician. ${ }^{59}$ Four years later, Ciba supported an endocrinological congress in Geneva organised by Prader. Since the end of the war, the focus in much of the clinical research undertaken by chemists and physiologists was on the pathologies of adrenal glands. In 1945, Fanconi and Grob started an interdisciplinary research group, which included five

\footnotetext{
${ }^{48}$ Patient record, StAZH, Z 810.3496.

${ }^{49}$ Patient record, StAZH, Z 810.3828.

${ }^{50}$ Letter from Andrea Prader to the GP, 16 December 1951, patient record, StAZH, Z 810.3498.

${ }^{51}$ Chandak Sengoopta, The Most Secret Quintessence of Life: Sex, Glands, Hormones, 1850-1950 (Chicago: University of Chicago Press, 2006), 154.

${ }^{52}$ See eg. Tanja Rietmann et al., 'Wenn Ihr Medikament eine Nummer statt eines Markennamens trägt: Medikamentenversuche in der Zürcher Psychiatrie 1950-1980', in B. Gnädinger and V. Rothenbühler (eds), Menschen korrigieren (Zürich: Chronos, 2018), 201-54.

${ }^{53}$ Allgemeine Richtlinien für die Einleitung und Durchführung der klinischen Prüfung [typescript, four pages], 5 April 1949, Akten Prof. Dr. Rolf Meier, Ciba, FO 10.00, Forschung. Pharma. Biologische Zweckforschung. Allgemeines.

${ }^{54}$ Such as patient records, StAZH, Z $810.3496 ; 810.3498 ; 810.3502 ; 810.3519 ; 810.3803 ; 810.3828$ and $520 \mathrm{~A}$. This practice is not limited to the drug cortisone. For example, patient $930 \mathrm{~A}$ received the drug Elipten for free.

${ }^{55}$ Letter from Andrea Prader to the GP, 16 December 1951, patient record, StAZH, Z 810.3498.

${ }^{56}$ See eg. patient records, StAZH, 642A and 884A.

${ }^{57}$ Letter from Andrea Prader to the patient's mother, 14 May 1963, patient record, StAZH, Z 810.3487.

${ }^{58}$ Eder, op. cit. (note 9), 613.

${ }^{59}$ Minutes of the meeting on 25 September 1959, Agenda seven, Ciba, Wisko-Protokolle.
} 
scientists from the Physiological Institute in Basel and researchers from Ciba's research laboratories. ${ }^{60}$ Prader also worked with Robert Neher, research associate of the chemical research laboratory of Ciba. ${ }^{61}$ In his unpublished autobiographical notes, Neher mentioned his 'long-term collaboration (...) with A. Prader' ${ }^{62}$ Together, they were following their research interests and decided to work on therapeutic endeavours, too. In 1955, they published an article on the increased aldosterone excretion in the Congenital Adrenogenital Syndrome (CAH), including a discussion of its pathogenesis. ${ }^{63}$ Neher was dealing with the results of the study over the following years and received laboratory samples from the Kispi. ${ }^{64}$ The thesis of a 'specific Na-excreting [Sodium] factor (...) as a kind of antagonistic of Aldosteron' would be of 'upmost importance for physiology but as well for clinical therapy', as Neher noted. ${ }^{65}$ Between 1956 and 1959, he collected urine samples from selected patients of the Kispi. He was able to isolate and synthesise first these sodium-excreting factors from these samples of urine and in a second step from the adrenal gland of pigs. However, after biological tests in vitro and in the clinic, Neher's assumed effect of an antagonistic of Aldosteron had to be rejected. Work of several years had become 'useless', he wrote with regret in his autobiographical notes. ${ }^{66}$

Patient records show how Prader supplied Neher with medical information about trials. But it also emerges how patients and their families had been cast in a new role. The clinic and the industry relied for their research on patients' urine samples for chemical analysis in industry ${ }^{67}$ The families were involved in collecting the samples. For example, Prader requested from the mother of Roberto* urine samples of her child ' 5 days a week' in order to 'continue with our research'. ${ }^{68}$ One year later, in November 1957, Prader informed her that they had not 'received enough urine' $(0.51)$. Neher would need the astonishing amount of 'at least $3.75 \mathrm{dl}$ up to 11 a day'. ${ }^{69}$ The results of such analysis structured treatment decisions, as in the case of 9-year-old Petra ${ }^{*}$. In 1957, she entered the hospital, because Prader was interested in steroid research of her urine. The costs of the hospitalisation were to be covered by 'the scientific fund'. This would be 'entirely justified'. ${ }^{70}$ For the urine samples, she had to stay in the hospital for 5 days. ${ }^{71}$ Because the urine showed no 'significant increase of the excretion of aldosterone', Neher considered the 'amount of work as not vindicated' and stopped the investigation. ${ }^{72}$ Usually, parents did not oppose such treatment regimes or deny support to these scientific collaborations. They put their trust in the practitioners and their authority. But there are exceptions, such as the parents of Eva*. In 1953, they complained about 'the scientific experiments' on their child. They refused the treatment arguing that it was too expensive. When informed that the costs could be covered by 'a scientific fund', the parents felt convinced of the nature of 'scientific experiments'. They succeeded in having Eva* discharged from hospital. $^{73}$

In short, the pharmaceutical industry influenced decision-making in the clinic with its supply of drugs and financial support. At the same time, the clinic and industry started co-operation, such as

\footnotetext{
${ }^{60}$ Guido Fanconi, 'Zur Pathologie der Nebennierenrinde', Helvetica Paediatrica Acta, 4 (1949), 15-22 (here 15).

${ }^{61}$ Unpublished memoires, Dr Robert Neher, 1994, Ciba, FO 5.03 1. Chemische Zweckforschung. Pharma: Einzelne Präparate.

${ }^{62}$ Ibid., 18.

${ }^{63}$ A. Prader et al., 'Erhöhte Aldosteronausscheidung beim kongenitalen adrenogenitalen Syndrom', Schweizerische medizinische Wochenschrift, 85, 45 (1955), 1085-8.

${ }^{64}$ We can identify at least three patients which were listed in the patient records as 'Ciba-trial patients' or 'Ciba-trial series'. They were part of the trial for the Sodium [Natrium] and Aldosterone research. Patient records, StAZH, Z 810.3803; 810.3833 and 520A, probably also patient Z 810.3508 .

${ }^{65}$ Neher, op. cit. (note 61).

${ }^{66}$ Ibid.

${ }^{67}$ Letter from Andrea Prader to the family, 27 June 1956, patient record, StAZH, Z 810.3833.

${ }^{68}$ Ibid.

${ }^{69}$ Letter from Andrea Prader to the family, 16 November 1957, patient record, StAZH, Z 810.3833.

${ }^{70}$ File Note, 15 July 1958, patient record, StAZH, Z 810.3803.

${ }^{71}$ Ibid.

${ }^{72}$ Letter from Robert Neher to Andrea Prader, 21 November 1958, patient record, StAZH, Z 810.3803.

${ }^{73}$ Case history, 28 September 1953, patient record, StAZH, Z 810.3484.
} 
the collaboration of Neher and Prader for research on the steroid hormone Aldosterone. Neher was interested in it because of new insights in physiology and chemical processes for the development of new synthetic drugs which Ciba could launch. Prader, on the other hand, hoped for new insight from his clinical research for his decisions in 'intersex' management. Both endeavours relied on the co-operation of the parents. They had to report side effects of the drug use and note the general well-being of the child for Prader. And they had to supply the industry with samples, not for therapeutic purposes, but for the scientific interest of the industry and the clinic.

\section{Laboratory facilities, genetics and the clinic}

A further basis for decision-making in 'intersex' management in the clinic was in laboratory medicine and new genetic insights. Nicolas Jewson has pointed out how laboratory medicine constituted a new phase of 'medical cosmology'. ${ }^{74} \mathrm{He}$ argued that laboratory medicine 'removed' the patient 'from the medical investigator's field' and strengthened 'the world view of the scientific research worker' with its focus on 'pathology in microscopical events'. ${ }^{75}$ Laboratory medicine fundamentally changed the treatment of 'intersex' through the notion of the 'chromosomal sex'. How did laboratory medicine change the notion of biological sex? And also, how did the terminology around 'intersex' adjust to new genetic insights around chromosomal testing in the early 1960s?

The notion of a chromosomal either female or male sex is connected with the so-called 'Barr body'. Its detection dates to the work of Murray Barr, professor at the University of Western Ontario in Canada, and his graduate student Erwart Bertram. In 1948, during research on the effects of stress on the nervous system of cats, they discovered 'a deeply staining body in the nucleus of the cell'. ${ }^{76}$ They observed that this body was demonstrated only in neural cells of female cats (not in male ones). One year later, they confirmed the discovery in humans at autopsy and published their results in the influential journal Nature. ${ }^{77}$ Chromosomal analysis simplified the determination of the genetic make-up of the child's sex. Before, only an invasive laparotomy could give comparable information of the gonadal make-up. ${ }^{78}$ The decision-making for sex determination was orientated on the gonads. Alice Dreger has pointed out that since the late nineteenth century, the medical experts had insisted that a person's 'true sex' could be determined via his or her gonads (testicles or ovaries). ${ }^{79}$ With the Barr body, this 'gonadal standard' had to be replaced, as, according to Miller, it resulted in 'indirect evidence about the sex chromosomal status' of the patient. ${ }^{80}$ Due to the Barr body, physicians were able to determine the 'true' (meaning the chromosomal) sex of children with $\mathrm{CAH}$ and born with virilised genitals. They achieved a new basis for decision-making.

The determination of the sex chromatin was originally difficult and required an invasive intervention, the examination of the epidermal nuclei in a small biopsy of skin. ${ }^{81}$ In the following years, further improvements allowed smears of the oral mucosa, ${ }^{82}$ and examinations of the nucleus white

\footnotetext{
${ }^{74}$ Jewson, op. cit. (note 20), 236-7.

${ }^{75}$ Ibid., 237.

${ }^{76}$ Fiona Alice Miller, 'Your True and Proper Gender: The Barr Body as a Good Enough Science of Sex', Studies in History and Philosophy of Biological and Biomedical Sciences, 37 (2006), 459-83 (quote from 460). For the history of 'chromosomal sex', see Peter S. Harper, A Short History of Medical Genetics (Oxford: Oxford University Press, 2008).

${ }^{77}$ Murray L. Barr and Ewart G. Bertram, 'A Morphological Distinction Between Neurons of the Male and Female, and the Behaviour of the Nucleolar Satellite During Accelerated Nucleoprotein Synthesis', Nature, 163 (1949), 676-7.

${ }^{78}$ This change is visible in Fanconi's textbook. Whereas, in the third edition, the gonadal sex is seen as decisive for sex determination, 2 years later, the fourth edition names the chromosomal sex as decisive. See Fanconi and Wallgren, op. cit. (note 36) and ibid., 4th edn (Basel: Benno Schwabe \& Co. Verlag, 1956).

${ }^{79}$ Dreger, op. cit. (note 13), 29. Also see Eder, op. cit. (note 13), 693 and Klöppel, op. cit. (note 13).

${ }^{80}$ Miller, op. cit. (note 76), 460.

${ }^{81}$ K. L. Moore et al., 'The Detection of Chromosomal Sex in Hermaphrodites from a Skin Biopsy', Surgery, Gynecology and Obstetrics, 96, 6 (1953), 641-8.

${ }^{82}$ Keith Moore and Murray Barr, 'Smears from the Oral Mucosa in the Detection of Chromosomal Sex', The Lancet, 266, 6880 (1955), 57-8.
} 
blood cells. ${ }^{83}$ Hans-Rudolf Wiedemann (1915-2006), a senior physician scientist at the Paediatric Hospital in Krefeld, investigated the morphology of the blood. He received 261 blood samples from several hospitals, 86 of the samples came from Switzerland. He developed the hypothesis that for correct sex determination, 500 cells should be analysed. If 6 of these 500 cells contained a drumstick like the Barr body, only demonstrable in female cells - the chromosomal sex would be female. ${ }^{84}$ In 1956, the Kispi tried to apply the simpler method of smears of the oral mucosa in its own laboratory. ${ }^{85}$ Prader wrote that 'the possible determination of the chromosomal sex stimulated and revolutionised research on intersexuality in an unprecedented way'. ${ }^{86} \mathrm{New}$ possibilities of diagnosis through technological innovation towards the end of the decade led to a rearrangement and reclassification of 'intersexual' syndrome in the late 1950s, as Marion Hulverscheidt has shown. ${ }^{87}$

With chromosomal sex, a further factor became decisive for decisions around treatment regimes for 'intersex' children. Prader was convinced of the importance of the determination of the 'right' sex for the correct treatment, 'to avoid therapeutic mistakes'. ${ }^{88}$ As we see in the case of 13-year-old Wilma*, determining 'chromosomal sex' became the precondition for any further treatment. A general practitioner (GP) referred the girl to the Kispi in autumn 1958. The mother 'had recognised a swelling between the legs during bathing the child'. ${ }^{89}$ The GP identified this swelling as 'an enlarged clitoris'. Prader and two assistants examining the child were unsure about the diagnosis. Because of the genitalia, they thought that it could be CAH. Prader decided to pursue standard diagnostic procedures. Besides handwrist images, they measured the 17-ketosteorid. Because the result was 'normal', they ruled out CAH. Smears of the oral mucosa were sent to Dr Wiedemann in Germany to determine the chromosomal sex. The result, however, was not clear. Wiedemann responded that the girl would be 'likely chromosomal male'. A second test resulted in 'definite male'. Because of these results, Prader's team was confused. A secure diagnosis would only be possible with an incision in the abdomen (laparotomy) to investigate the gonads. Just a couple of days later, the surgeon Max Grob conducted the surgical exploration with biopsy and recognised testicular tissue..$^{90}$ Because of these various procedures, Prader concluded the diagnosis of 'true hermaphroditism', meaning an individual born with ovarian and testicular tissue. As in case of Wilma ${ }^{\star}$, chromosomal sex determination became a standard diagnostic procedure at the Kispi in order to determine 'the true sex' as a basis for decision-making. ${ }^{91}$

The treatment decisions no longer just depended on the clinical assessment but also on laboratory medicine. Physicians and parents alike expected treatment recommendations based on the latest diagnostic procedures. In case of $\mathrm{CAH}$, a new aspect in the question of which direction sex should be adjusted came to the fore with chromosomal sex. And from 1949, cortisone also reinforced the 'underlying assumptions about the body's physical nature', with a clear female or male sex. ${ }^{92}$ Earlier

\footnotetext{
${ }^{83}$ H. R. Wiedemann, H. Romatowski and M. Tolksdorf, 'Geschlechtsbestimmung aus dem Blutbilde: Grundlagen-Anwendung-Bedeutung’, Münchner Medizinische Wochenschrift, 98 (1956), 1108-12 (here 1109).

${ }^{84}$ Ibid. These results were discussed at the Symposium on Nuclear Sex in London at the King's College medical school. In addition to Wiedemann and Overzier, Prader attended as an expert for research on 'intersexuality'. D. Robertson Smith and William M. Davidson (eds), Symposium on Nuclear Sex (London: William Heinemann, 1958). Prader published the following article in the proceedings: Andrea Prader and R. E. Siebmann, 'Congenital Adrenal Insufficiency With Lipid Hyperplasia of the Adrenals and Female Genitalia in Boys', in ibid., 62-5.

${ }^{85}$ M. Lupatkin and A. Prader, 'Welches ist die einfachste Methode zur Bestimmung des chromosomalen Geschlechts?', special print, originally published in Schweizerische Medizinische Wochenschrift, 86, 33 (1956), 1-6 (here 4).

${ }^{86}$ Andrea Prader, 'Intersexformen mit normalen äusseren Genitalbefund', Annales Nestlé, 14 (1959), 2-24 (quote from 3).

${ }^{87}$ Marion Hulverscheidt, 'Intersexualität zwischen 1957 und 1961. Zur Bedeutungsverschiebung und Neuorientierung im deutschsprachigen Raum', Sexuologie, 24, 3-4 (2017), 147-58 (here 157).

${ }^{88}$ Andrea Prader, 'Gonadendysgenesie und testikuläre Feminisierung', Schweizerische Medizinische Wochenschrift, 87, 12 (1957), 278-85 (quote from 278).

${ }^{89}$ Patient record, StAZH, Z 810.3810.

${ }^{90} 3$ December 1958, patient record, StAZH, Z 810.3810.

${ }^{91}$ See Fanconi and Wallgren, 4th edition, op. cit. (note 78), 290. Besides the determination of the chromosomal sex, they mention the determination of the of urinary 17-Ketoteroids and the consideration of the somatic development.

${ }^{92}$ Fausto-Sterling, op. cit. (note 13), 7.
} 
Fanconi had advised to not give definitive advice and to propose to give the child a sex-neutral name if the sex of the child was in doubt. ${ }^{93}$ With new laboratory methods, such an approach changed.

In clinical practice, Prader and his team no longer made clinical decisions on suspected intersexuality' without determination of chromosomal sex. Prader soon implemented various new methods of sex determination in Zurich. Smear tests were introduced in the 1950s, and in the 1960s, the Karyogram introduced by Schmid - came into use as well. Physicians still occasionally reverted to abdominal surgery to locate the gonads - especially in case of suspicion of 'Hermaphroditism verus' - the presence of both ovarial and testicular tissue, as in the case of Wilma*.

Whereas the focus of clinical research in the 1940s and 1950s focused on the syndrome CAH and the new insight regarding the chromosomal sex, during the late 1950s, it shifted to genetic diseases such as Klinefelter's syndrome. In 1959, researchers discovered that several congenital 'malformations' were caused by chromosomal aberrations. As Ilona Löwy has shown, this has been presented as a turning point for clinical genetics. ${ }^{94}$ The medical interest turned to children with a different chromosomal sex than their physical appearance looked like. Prader mentioned in 1959 that research showed that people with 'Klinefelter's syndrome have the chromosomal formula XXY' ${ }^{95}$ Such children appeared male, although the chromosomal sex of children with Klinefelter would be 'mostly or always (this would be still not clear) female'. ${ }^{96}$ Signs and symptoms recognised by Prader were gynecomastia (male breast enlargement) and small testicles. It would be 'the first known form of intersexuality with a difference between the chromosomal and gonadal sex - and not between the gonadal and genital one'. ${ }^{97}$ Besides Klinefelter, interest in Turner's and testicular feminisation syndromes (today: complete androgen insensitivity syndrome) grew as well. Children with Turner's syndrome - or its predecessors Ullrich Turner's syndrome and Bonnvie Ulrich syndrome - appeared female. Recognised signs and symptoms were growth retardation, lack of menstruation and often a webbed neck. During our period, such children were considered to be most likely chromosomal male. ${ }^{98}$ Children with the testicular feminisation syndrome appeared female but with a male sex chromosomal character. Fanconi and Prader mentioned this for the first time in 1955 as a 'special form' of 'Pseudohermaphroditism masculinus'. According to these two authors, patients lacked a uterus, and the vaginal cavity was only shallow. ${ }^{99}$ Prader subsumed all three syndromes under 'forms of intersexuality with normal external sex organs' and emphasised the discrepancy between the chromosomal sex and the genitals. ${ }^{100}$ The pursuit of genetic innovation was rapidly becoming important for diagnosing these syndromes, which had previously not attracted much interest from paediatricians. ${ }^{101}$

Prader recognised the increasing scientific importance of congenital chromosomal disorders and tried to extend his laboratory capacity. At the end of 1962, he wrote to the dean of the medical faculty that he was going to apply to the government of Zurich for funding for a new chromosomal laboratory

\footnotetext{
${ }^{93}$ See G. Fanconi and R.F. Landolt, 'Die Erscheinungsformen des “Dyscorticismus” beim jungen Säugling', Helvetica Paediatrica Acta, 4 (1949), 22-42 (here 38).

${ }^{94}$ Ilona Löwy, 'How Genetics Came to the Unborn - 1960-2000', Studies in History and Philosophy of Biological and Biomedical Sciences, 47 (2014), 154-62.

${ }^{95}$ Prader et al., 'Genes on the Y Chromosome Influencing Rate of Maturation in Man: Skeletal Age Studies in Children with Klinefelter's (XXY) and Turner's (XO) Syndromes', special print, originally published in The Lancet, 274, 7095 (1959), 2-12 (quote from 4). They referred on P. A. Jacobs and J. A. Strong, 'A Case of Human Intersexuality Having a Possible XXY SexDetermining Mechanism', Nature, 183, 4657 (1959), 302-3. Initial description of this syndrome due to Klinefelter and Reichstein in 1942.

${ }^{96}$ Andrea Prader, Intersexualität, special print, originally published in A. Labhart, Klinik der inneren Sekretion (Würzburg: Universitätsdruckerei, 1957), 656. Therefore, he classified Klinefelter under 'Pseudohermaphroditism femininus'.

${ }^{97}$ Ibid.

${ }^{98}$ Ibid., 668.

${ }^{99}$ Guido Fanconi and Andrea Prader, 'Eine besondere Form des Pseudohermaphroditismus masculinus, das Syndrom der testikulären Feminisierung', Deutsche Medizinische Wochenschrift, 37 (1955), 405.

${ }^{100}$ Prader, op. cit. (note 86).

${ }^{101}$ This is reflected in the publications of the Children's Hospital in Zurich. Whereas, in the early 1950s, the researchers put a strong emphasis on CAH, after 1953, publications on Klinefelter's, Turner's and testicular feminization syndromes rapidly became significant.
} 
because of the 'enormous importance of congenital chromosomal disorders for medical science'. ${ }^{102}$ Prader also mentioned that a privately financed work group consisting of the Kispi and the Zoological Institute of the university had provided the laboratory capacity. The government of the Canton of Zurich approved funding for the chromosomal laboratory, two senior assistants, an assistant physician and two lab assistant positions. The government justified this with the 'declining of infectious diseases and the increasing importance of inherited birth' diseases. It would be necessary to 'maintain and strengthen the prestige of the Children's Hospital' in an international environment. ${ }^{103}$ The geneticist Werner Schmid (1930-2002) took over the management of the new laboratory in the same year. ${ }^{104}$ This led to increasing research capacity in the emerging field of congenital chromosomal disorders.

Knowledge of genetics and new possibilities in sex determination made things visible that were unrecognised before. In 1958, Prader and the psychiatrist Walter Züblin (1919-1990) organised a screening programme of pupils in school classes for 'imbeciles' in order to investigate any correlation between Klinefelter's syndrome and 'imbecility'. Several children from the screening were later to become patients at the Kispi. ${ }^{105}$ Syndromes like Klinefelter were hitherto diagnosed during puberty (when signs of the syndrome occurred, and the gonads were differentiated). Children who had so far been considered healthy were now pathologised and subjected to diagnostic and therapeutic interventions. Our sample contains four children where the diagnosis of Klinefelter was discovered through such screening. ${ }^{106}$ The diagnosis of these syndromes had virtually no impact on therapeutic measures for Prader. ${ }^{107}$ In cases of testicular feminisation syndrome, he remained sceptical towards therapeutical interventions. He considered it possible to trigger sexual characteristics and menstruation with hormonal therapy, but he doubted whether such treatment would be appropriate. Often, he opined, patients remained happier untreated. He advised deciding case by case and take the physical and psychological situation of the patient into account. ${ }^{108}$ But Prader considered a correct diagnosis of these differences of sexual development as important for matters of heredity, the prognosis of growth, puberty and fertility in order to prevent wrong decisions and therapeutic mistakes. ${ }^{109}$

We see how laboratory medicine reconceptualised sickness and health with new notions of biological sex. The changing understanding of hormones, the diagnostic possibilities of chromosomes and shifts in surgery practices complicated the medical quest for a person's 'true sex'. It also changed the role of medical authority in decision-making, as the authority of the physicians was augmented with the authority of the scientific facts of the laboratory. However, the shift in medicine from 'a discipline in its own right' to 'an applied science' did not remove the patient from 'medical cosmology'. ${ }^{110}$ The decision-making process in the case of chronic disease management relied on laboratory medicine, but it was bound up with social interaction between the practitioners, the patient and the family.

\section{Changing relationships between medicine and the families}

Paternalistic medicine has been characterised as a form of medicine in which doctors take decisions on behalf of their patients. ${ }^{111}$ Much of the 'new' social history of the hospital has focused on this aspect of

\footnotetext{
${ }^{102}$ Letter of Andrea Prader to Professor R. Hotz, Dean of the Medical Faculty, 28 December 1962, UZH, G.4.302.185, Prader, Andrea, 1919-2001.

${ }^{103}$ Erhöhung des Forschungskredites für Schaffung eines Chromosomenlabors, 15 August 1963, Regierungsratsbeschlüsse, StAZH, MM 3.108 RRB 1963/3174.

${ }^{104}$ Jahresbericht des Kinderspitals Zürich, 1963, 8.

${ }^{105}$ Andrea Prader et al., 'Die Häufigkeit des echten, chromatin-positiven Klinefelter-Syndroms und seine Beziehungen zum Schwachsinn', special print, originally published in Schweizerische Wochenschrift, 88, 38 (1958), 1-10.

${ }^{106}$ Patient records, StAZH, Z 810.2729; 810.2731; 810.2874 and 810.2888.

${ }^{107}$ Prader, op. cit. (note 88), 278.

${ }^{108}$ Ibid., 281.

${ }^{109}$ Ibid., 278.

${ }^{110}$ Jewson, op. cit. (note 20), 238.

${ }^{111}$ Leclercq, op. cit. (note 21).
} 
hospital medicine. ${ }^{112}$ This is of course problematic when it comes to children as patients, in particular with children as young as a few months. ${ }^{113}$ But we note that the role of the family in medical settings is still neglected in historiography. For us, it is essential to trace the relationship between the family and the clinic in order to better understand if and how patient and its family were involved in clinical 'intersex' management.

As shown with the pharmaceutical, genetic and laboratory-technical 'revolution', children became chronic patients. This created a new basis for decision-making. Patients stayed in long-term contact with physicians, sometimes for as long as 20 years. Prader, for instance, was still working with his patient Eric* when he was already over 40 years old, and Prader had retired. ${ }^{114}$ Children could develop an emotional relationship to their physician. They wrote letters asking for advice or sent postcards from their holidays, ${ }^{115}$ occasionally they drew paintings for the doctors.

Through the patient records, the physicians possessed information about the health and social condition of the child over several years. These notes were an important basis for further treatment decisions but also for new research insights. The co-operation of the patients and their family was of paramount importance though. Older patients or the parents of young children gave regular reports on the progress of medication, sent urine for the 17-ketosteroid determination and described their general condition. ${ }^{116}$ The pharmaceutical industry and clinical practice were now dependent on the parents and the children in two ways. First, they required reliable and regular samples of urine to evaluate the therapeutic effort. And second, for measuring the long-term treatment with the drug, they had to be sure that the children were taking the prescribed drug.

The collaboration between industry, parents, patient and the clinic was a necessary condition for the treatment of 'intersex' in our period. The basis for such interactions was the assumption that life without a clear gender identity was unimaginable - for physicians, as much as for parents and their children. Differences between the sexes had been explained by biology since the second half of the eighteenth century. ${ }^{117}$ In the 1950 s and 1960 s, social pressure to conform to gender roles was considerable. Motherhood was represented in this model as 'an all-encompassing identity'. ${ }^{118}$ Women as mothers were responsible for the private household and had to bring up the children. The father was responsible for interactions of the family in the public sphere and had to feed the family. ${ }^{119}$ These roles in society, stratified by sex, were not explained culturally or socially but were considered as biological facts. In this way, the naturalising of social functions of women and men had a reciprocal effect on biological concepts of the sexes. Although scientists were aware that there was more in nature than the female-male dichotomy, the assumption 'that there are only two sexes' was not questioned. ${ }^{120}$ They understood 'intersexual' persons as deviations from nature which ought to be normalised. The increasing pressure to create a clearly sexed body with a clear gender identity influenced not only medical practices but also the way in which physicians communicated with the patient and his or her family.

\footnotetext{
${ }^{112}$ Guenter B. Risse, Mending Bodies, Saving Souls. A History of Hospitals (New York: Oxford University Press, 1999).

${ }^{113}$ Iris, Ritzmann, 'Junge Patienten in alten Spitälern - Stichworte zur Bedeutung von Kindern für die Hospitalgeschichtsforschung', Historia Hospitalium, 27 (2011), 87-94.

${ }^{114}$ Patient records, StAZH, Z 847.1498 and 736.217.

${ }^{115}$ Patient record, StAZH, Z 810.3516 .

${ }^{116}$ See eg. patient records, StAZH, Z 810.3485 and 810.3496 .

${ }^{117}$ See Claudia Honegger, Die Ordnung der Geschlechter: Die Wissenschaften vom Menschen und das Weib, 1750-1850 (Frankfurt: Campus, 1991).

${ }^{118}$ Rebecca Jo Plant, Mom: The Transformation of Motherhood in Modern America (Chicago: University of Chicago, 2010 ), 3.

${ }^{119}$ For Switzerland, see David Gugerli, 'Das bürgerliche Familienbild im sozialen Wandel', in Thomas Fleiner-Gerster, Pierre Gilliand and Kurt Lüscher (eds), Familien in der Schweiz (Freiburg Schweiz: Universitätsverlag, 1991), 59-74. In the American context, Fausto-Sterling emphasised a conservative background in the 1950s. See Fausto-Sterling, op. cit. (note 13), 72. For a theoretical approach, see Moira Gatens, 'Institutions, Embodiment and Sexual Difference', in Moira Gatens and Alison Mackinnon (eds), Gender and Institutions: Welfare, Work and Citizenship (Cambridge: Cambridge University Press, 1998), 1-15.

${ }^{120}$ Fausto-Sterling, op. cit. (note 13), 46.
} 
Strategies of communication depended on the age of the child. Physicians did not communicate openly with children. Since the turn of the twentieth century, scientific concepts in physiology and psychology conceptualised childhood as a development process and as an independent stage of life. ${ }^{121}$ But children were seen more as objects of medical investigation than equal partners for decision-making. The underlying assumption was that they would be too young to understand the consequences of their 'disease'. ${ }^{122}$ Usually, physicians interacted with the mothers as the letters in the patient records emphasise. This corresponds to the social role of the mother, who was seen responsible for the education of their children. ${ }^{123}$ The transfer of such ideology became visible in psychological concepts which focused very much on the mother and made her responsible for the healthy development of the child. ${ }^{124}$ Additionally, the communication depended on the diagnosis, particularly on the external visibility of the 'intersexual' condition. It was orientated on shared assumptions about the 'normal' body with its focus on a clear female or male sex. Prader and his team communicated openly with parents of children with 'Congenital Adrenogenital Hyperplasia' (CAH) who had 'unclear' genitals. The lack of clear female or male sex was visible for the family. Often it was the reason why a child entered the hospital. The parents worried because of this fact and expected medical support. The precondition for therapeutic measures in case of $\mathrm{CAH}$ was the knowledge of the make-up of chromosomal, gonadal and genital sex which had been communicated to the parents in order to involve them in the decision-making regarding the sex adjustment.

In forms of 'intersexuality' not immediately visible such as Klinefelter's and Turner's syndromes, Prader responded differently. He recommended not informing patients and parents of the fact that the chromosomal sex did not correspond to the outer appearance. Our sample contains twelve patient records in which the chromosomal sex had been concealed from parents and patient. ${ }^{125}$ In 1956, Prader, together with $\mathrm{M}$ Lupatkin, published an article about the different methods to determine chromosomal status. One key factor for the assessment of the various methods was the aspect of patient information. According to the authors, the determination of the chromosomal sex was best done using smears. The parents would not notice that the physicians doubted the child's sex. They regarded the informing of the patient and the family to be negligible. In the case of a skin biopsy, however, they feared that it could 'be hardly implemented without the knowledge of the patient'. ${ }^{126}$

Concealing the chromosomal sex from the parents followed a paternalistic understanding of medicine: The argument was that one should not burden either the patient or the parents with diagnostic details of no practical consequence. It also corresponded to the binary logic of decision-making about sex. If the outer appearance of a child looked either male or female and there were no physical signs for an 'intersex' condition, the physicians saw no reason to inform the parents. There was no therapeutic measure necessary to create a clearly sexed body. On the contrary, Prader was convinced that it would be 'ill-advised to tell the patients, or their relatives the chromosomal sex of children with normal genitals'. ${ }^{127}$

The paediatricians expected that the parents would inform their children 'at the right time' (eg. during puberty) about possible problems such as sterility. The responsibility to inform was handed over to the parents, who had themselves not been fully informed. Unsurprisingly, this was a challenge for many families, who ended up concealing much from their children. There are quite a few cases in our records

\footnotetext{
${ }^{121}$ Steven Mintz, 'Why the History of Childhood Matters', Journal of the History of Childhood and Youth, 5 (2012), 15-28 (here 20). For the link between development and a modern notion of childhood, see Carolyn Steedman, Strange Dislocations: Childhood and the Idea of Human Interiority, 1780-1930 (Cambridge, MA: Harvard University Press, 1995).

${ }^{122}$ We have written elsewhere on the experiences of 'intersex' children based on interviews: Andrea Althaus et al., "'Schnitt im Kopf”. Zur Rolle der Kommunikation in der Behandlung “intersexueller” Kinder am Kinderspital Zürich in der zweiten Hälfte des 20. Jahrhunderts', Werkstatt Geschichte (in press, autumn 2021).

${ }^{123}$ See Plant, op. cit. (note 118).

${ }^{124}$ Heidi Witzig, 'Kindheit', Historisches Lexikon der Schweiz online (e-HLS), 2008, http://www.hls-dhsdss.ch/textes/d/ D10395.php (last accessed 27 December 2016).

${ }^{125}$ Patient records, StAZH, Z 810.2715; 810.2729; 810.2857; 810.2866; 810.2884; 810.2886; 810.3810; 810.3811; 810.3816; 810.3490; 854K and 221A.

${ }^{126}$ Lupatkin and Prader, op. cit. (note 85).

${ }^{127}$ Prader, op. cit. (note 88), 281.
} 
where patients contacted their former physicians, often during adulthood, when they were trying to start their own family. Eric ${ }^{\star}$, for instance, born in 1954, received his diagnosis of 'Pseudohermaphroditism masculinus internus' ${ }^{\prime 28}$ and the related sterility at the age of 17 during an outpatient consultation at the Kispi in September 1972. Two years earlier, his mother had been informed that Eric ${ }^{\star}$ would have testes but also 'some female structures', and that he would be 'sterile'. ${ }^{129}$ The patient record notes that 'since the conversation with Prader he was very upset'. He 'blamed his mother severely'. Right after the conversation, Eric ${ }^{\star}$ disappeared. The police had to be contacted. Prader noted that he would be 'very affected'. But he had the impression that 'the discussion went well. The patient was reasonable, perhaps a little bit scared'. ${ }^{130}$ In 1975, 3 years after the incident, Eric's general practitioner (GP) got in touch with Prader. Eric $^{*}$ had told him that he still was not fully informed. The GP asked whether Prader could inform him adequately or whether he should handle it himself. ${ }^{131}$ Five days later, Prader answered the letter. He said that the GP ought to inform the patient about male sex hormones, and sexual aspects of the disorder. 'Normal sexual relationships' would be possible but 'sterility would be most likely (an analysis of the semen will be made)'. 'His problems in contact with girls are probably rooted in his knowledge about the anomaly of his testes.' ${ }^{132}$

The patients were involved in a paternalistic physician-patient relationship, but they still had a scope of action - and could influence the clinical decision-making with resistance. Young adults quite often began to refuse treatment, and at home, they sometimes did not take the prescribed cortisone or not the correct dosage of it. Side effects were often the reason given for abrupt stops in medication. Bea ${ }^{\star}$, for example, eventually refused to take the drug. Prader decided after a chat with her to stop any further therapy of CAH. ${ }^{133}$ In the patient record, he noted that she was already 'relatively old' and would have 'found her place in life'. Letters reveal how patients dealt with consequences of the treatment, and how they assessed their own quality of life. A letter by Lisa ${ }^{\star}$ documents the consequences of treatment, the trade-off between the desired medical effect of the drug and the strong pain as a side effect. She had started to receive medical treatment in 1933, when she was 1 year old. At the age of 17, she consulted Prader to ask 'what is wrong with her. ${ }^{134}$ She had not had her 'first menstruation yet', and she had 'to use sand paper' on her face to prevent unwanted facial hair. In Summer 1958, she wrote Prader a long letter. She was already 26 years old but had remained in contact with Prader for almost a decade. First, she thanked him for the 'beneficial effects' of cortisone. She mentioned that it did indeed 'solve several problems', but that it also 'led to new ways of thinking'. She went on to describe how she 'fe[lt] like someone who [was] allowed only a brief glance at a beautiful country but who is never allowed to enter to stay'. Most likely, she was referring to the treatment with cortisone. She was indeed 'looking more female' now with the help of the drug, and without having had her menstruation, she would 'only look like a woman, but not actually be a woman'. A few months later, Lisa* stopped taking the cortisone. She disappears from the files and we do not know what became of her in subsequent years. ${ }^{135}$ To summarise, clinical practices were clearly orientated towards a concept of paternalistic medicine. The physicians as medical experts put the parents under pressure and did not in any case communicate openly with the parents. Younger children were excluded from information and the decision-making process. Older children had a certain scope of action and could develop some agency. But it is evident that they were not much involved in decisions around sex adjustment. Here, the physicians did act with the parents, and medical disciplines such as psychiatry - but did not include the children in the decision-making process.

\footnotetext{
${ }^{128}$ This diagnosis corresponds to Complete Androgen Insensitivity Syndrome (CAIS), most likely he had a partial CAIS.

${ }^{129}$ Nevertheless, Eric ${ }^{\star}$ was in treatment from 1958 on 21 September 1970, patient records, StAZH, Z 847.1498 and 736.217.

${ }^{130}$ File note, 30 January 1972 , patient record, StAZH, Z 847.1498.

${ }^{131}$ Letter from the GP of Eric ${ }^{*}$ to Andrea Prader, 23 April 1975, patient record, StAZH, Z 847.1498.

${ }^{132}$ Letter from Andrea Prader to the GP of Eric ${ }^{\star}, 28$ April 1975, ibid.

${ }^{133}$ Patient record, StAZH, Z 810.3519.

${ }^{134}$ Patient record, StAZH, Z 810.3485.

${ }^{135}$ Ibid.
} 


\section{The question of the 'right' sex: doctors, parents and psychiatry}

The discovery of cortisone and new technologies for chromosomal testing led to an increased medicalisation of 'intersex' children. Because it was possible to stop virilisation in female patients, cortisone had an influence on genital surgery and the questions in which direction a child with ambiguous sex should be surgically adjusted. As Anne Fausto-Sterling has shown, the possibilities of the surgical and hormonal 'suppression of intersexuality' resulted in a new medical imperative: 'to catch mixed-sex people at birth and convert them, by any means necessary, to either male or female'. ${ }^{136}$ However, what Fausto-Sterling has called an 'age of conversion', we would describe instead as a process of normalisation. ${ }^{137}$ Despite a certain standardisation and the establishment of protocols, clinical decision-making continued to function on a case-by-case basis and involved different actors in the decision-making process. Although specialist physicians such as Prader had great authority, they did not act autonomously. 'Intersex' management in the age of a more and more specialised paediatric medicine illustrates the interdependence between medicine and societal gender perceptions, and the transfers between science and society.

Prader relied for his treatment recommendations on different medical actors. Besides surgeons, psychiatrists played a growing role in questions of sex adjustment at the Kispi since the end of the 1940s. Psychiatric examinations were intended to consider in which direction a child should be 'normalised'. ${ }^{138}$ The importance of this discipline in Swiss 'intersex' management can be attributed to Manfred Bleuler (1903-1994), son of the famous psychiatrist Eugen Bleuler (1857-1939), who had coined the term 'schizophrenia'. Bleuler junior became medical director of the psychiatric hospital in Zurich in 1942. He was an expert in psychiatric endocrinology, did research on the psychosexuality of 'hermaphrodites' and established the mental disorder of 'endocrinological psychosyndrome'. ${ }^{139}$ Together with other psychiatrists, he conducted psychiatric examinations of patients of Prader. In case of 5-year-old Beni*, when the child entered the hospital, the parents had already been informed about the uncertainty of the child's sex. He came in 1965 from Germany to Zurich in order to clarify the sex, for diagnostic reasons and therapeutic recommendations. Prader informed Beni's ${ }^{\star}$ parents of the treatment choices: Either they would have to approve a complete sex change and bring up their child as a girl according to its chromosomal sex, or, if they preferred to continue raising Beni* as a boy, further surgery would be necessary in order to achieve 'the removal of the ovaries, the further improvement of the phallus and the treatment with corticoids'. The parents saw 'a retransformation into a girl as out of the question unless it would be really the best for their child'. ${ }^{140}$ But what was the best for the child? To answer this difficult question, Prader referred Beni* to the psychiatrist Alfons Weber (1921-2013) for a psychiatric observation and forwarded him the case file. ${ }^{141}$ In 1965, Weber became the head of the Kispi's child psychiatric department, which opened in the same year. The institutionalisation of child psychiatry in paediatrics proceeded in the second half of the twentieth century. ${ }^{142}$

On the basis of the patient records, a conversation with Beni's ${ }^{\star}$ parents and an IQ test, Weber supplied his psychiatric expertise. According to the report, the mother of the child mentioned that neither she nor her husband could imagine raising him as a girl. Weber followed standards in the psychiatric evaluation of children when he explored Beni's ${ }^{\star}$ playing behaviour in order to look for female and male interests.

Weber considered arguments for and against a sex change. He concluded that Beni* generally felt male, but that his behaviour showed some female characteristics. As reasons for a change in the female direction, he mentioned the possibility of reconstructing 'nearly normal female genitals' with a 'normal capacity of reproduction', which is somewhat surprising given that his expertise was supposed to be psychiatric. Most likely, he was supported by surgical expertise. Leaving the child in his male role could

\footnotetext{
${ }^{136}$ Fausto-Sterling, op. cit. (note 13).

${ }^{137}$ See for this discussion Eder, op. cit. (note 24 ).

${ }^{138}$ In total, our samples contain forty-nine psychiatric examinations of forty-one children treated at the Kispi because of 'intersexuality'. The earliest is from 1946.

${ }^{139}$ See Klöppel, op. cit. (note 13), 487.

${ }^{140}$ Patient record, StAZH, Z 810.3819.

${ }^{141}$ Ibid.

${ }^{142}$ Jahresbericht des Kinderspitals Zürich, 1965, 5.
} 
harm him in adulthood. What would happen if he was going to recognise that he could be 'a reproducible woman' instead of 'half of a man'? Furthermore, his prospective height was around $1.5 \mathrm{~m}$ and contributed to him being raised as female rather than as a male. On the other hand, arguments in favour of maintaining his male role were that he had already started to grow up as a boy, his 'gender identity was male (albeit not fully)', and a sex change 'at this stage' could be connected with 'a substantial trauma'. According to Weber, 'experience suggested that children who had a sex change at this age would still feel the gender they had been initially raised in'. Beni* could probably become homosexual, an 'enormous handicap' as Weber mentioned. Furthermore, 'the clitoris was so enlarged' that it would 'be possible to fulfil the function of a penis in adulthood'. ${ }^{143}$

The decisions Weber made were based on different factors which also played a role in other psychiatrists' examinations. First, he investigated the gender identity of the child. This was based on contemporary social and cultural norms and values. Playing with dolls was considered female, and playing with cars as male. Boys who were shy or did not fight with other boys were considered feeling more female. Girls who showed interest in technology or were cheeky were considered as boyish. Second, he focused on reproduction. Was the child capable of reproduction? If not, what would be the psychological consequences for the development? Third, he considered the age of the child. Weber thought that a surgical intervention would not be advisable later in childhood. But this insight was built on other assumptions than Wilkins and Money's Hopkins protocol. In Zurich, Prader referred to the notion of psychosexuality by the Swiss psychiatrist Walter Züblin. ${ }^{144}$ Two years prior to the Hopkins protocols, in 1953, Züblin published a study with twelve patients of CAH and suggested a weak psychosexuality in all patients. He traced this back to his tutor Manfred Bleuler and the concept of the 'endocrinological psychosyndrome'. ${ }^{145}$ Bleuler's notion of psychosexuality differed from that of Wilkins. Whereas Wilkins was convinced that a female or male sexual orientation was learned during upbringing, he recommended the early surgical adjustment of the genitals to the chosen sex before the children learned their 'gender role'. ${ }^{146}$ Bleuler was convinced that children with CAH would have 'a weak and slightly differentiated psychosexuality' and therefore a sex adjustment at a very young age would not have consequences for their gender identity. ${ }^{147}$ Additionally, he focused on the consequences of the adjustment for sexuality. On the one hand, he investigated the potential for penetrative intercourse. On the other hand, he took sexual desire and orientation into account. A 'normal' (meaning heterosexual) orientation was decisive. A sex change could, as Weber mentioned, lead to homosexual desire. The reference to homosexuality such as in Beni's $s^{*}$ case is, light of other psychiatric examinations, rather more of an exception. Finally, the technical possibilities of a surgical intervention were also taken into account. Taking all these factors into consideration, Weber concluded that difficulties would arise in either case, but if Beni* stayed in the current gender role, he would be better able to process the difficulties when made fully aware of his condition in adulthood. Therefore, the psychiatric advice given suggested leaving Beni* $^{\star}$ to grow up as a boy. Prader followed suit and recommended to the parents to leave Beni* in his male role in accordance with the psychiatrist's advice. When the parents had agreed, Prader informed the physician in Germany about the necessary surgical procedure: the removal of the ovaries, a penis enlargement and subsequent treatment with hormones. ${ }^{148}$ The removal of the ovaries would be necessary for stopping breast development and menstruation. Prader was aware of the scope of the intervention. In the letter to the physicians, he mentioned that if the parents could not commit to this major intervention, he could offer a compromise: to allow Beni* to grow up as male but to not begin treatment with cortisone. ${ }^{149}$

\footnotetext{
${ }^{143}$ Patient record, StAZH, Z 810.3819.

${ }^{144}$ For the differences between Money and Züblin's notion of psychosexuality, see in detail Klöppel, op. cit. (note 13), 488-94 and Eder, op. cit. (note 9).

${ }^{145}$ See Manfred Bleuler, Endokrinologische Psychiatrie (Stuttgart: Georg Thieme Verlag, 1954).

${ }^{146}$ Eder, op. cit. (note 9), 629.

${ }^{147}$ Ibid.

${ }^{148}$ Patient record, StAZH, Z 810.3819.

${ }^{149}$ Letter of Andrea Prader to ms Dr med B. of the municipal hospital Munich, 3 February 1966, patient record, StAZH, Z 810.3819.
} 
This case clearly confirms that quite a few of Prader's cases were far from being clear, regardless of his published treatment advice. Prader evaluated what he considered to be the best interests of the child, but he also involved the families and other medical experts in the process. Prader's clinical process may have been influenced by U.S. practices, but it certainly was not determined by the Hopkins protocols as a treatment standard. The idea to allow a nongendered identity or allowing nature to simply take its course without intervention, however, was not considered by Prader and therefore not recommended to the parents. This was clearly outside of Prader's or anybody else's world at the time.

Prader influenced the decision of the parents by giving a recommendation what they should do. But he also informed them about other possibilities. In 1957, the 2-year-old child Nils came from Sweden to Zurich. He suffered from various disorders which were not diagnosed with certainty, such as 'dystrophy', nutritional disorders and genital malformation. After birth, the child was first declared to be a girl, then that was changed, and the child was considered to be a boy. His mother was Austrian, and therefore German-speaking. Her sister was a physician and advised her and her child. During Nils` stay in Switzerland, he stayed with a former Swiss housemate in the eastern part of the country. The parents remained in Sweden. The mother corresponded with Prader at the Kispi. Although Prader's diagnosis was 'Pseudohermaphroditism masculinus' - Nils* was chromosomal male - he recommended reassigning the child's sex again in the direction of a girl. His arguments were largely based on surgical concerns. Nils ${ }^{\star}$ had a severe Hypospadias scrotalis (ie. the urethra was on the underside and not on the tip of the penis). Several difficult surgeries would be necessary to fix this problem. Prader argued that surgically it would be easier to transform the child's genital into a clitoris and let it undergo substitute therapy with hormones in puberty. In his view, the child was not too old for such a sex change, but he emphasised that the parents had to decide soon. Nils ${ }^{\star}$ mother struggled with a decision, as documented in a substantial correspondence with her in the case files. Her letters show the difficulties of the case very clearly. She informed the physician in charge, Dr Ruth Illig (1924-2017), that 'it would be almost impossible to say whether a man without an intact penis would be happier than a woman with male chromosomes and no uterus...'. She also said that she feared the reaction of the environment. During the first sex change, 'her siblings had found it really difficult to accept it'. Now, 'her environment would be very cautious and reluctant to even speak about her child. Nobody would ever ask directly for the 'boy'. She also worried about the fact that many people were aware of the 'problematic disorder'. Therefore, she felt obliged to acquaint her child early 'with all his metamorphoses'. She concluded that she was not ready to take any decision just yet. She could not approve the proposed intervention into what she called human integrity unless fully convinced about it. ${ }^{150}$

The reflections of Nils* mother express what she did take into account for a decision: She weighed the facts before making a decision and considered factors such as penetration or reproduction. She asked herself if a boy without an intact penis would be happier than a woman who cannot bear children. A further important criterion was the reaction of their environment. The fact that they could inform Nils* later in his life about the possible sex change would force her to tell him about the sex adjustment during childhood. Although she was very much conscious that it would be almost impossible to decide on behalf of her child, she did not question, in general, the urgency of making a decision about the 'right' sex. But despite the pressure applied by Prader to take a decision before the child was too old, she was able to resist and to postpone it until she could convince herself what to do.

The decision must have been difficult for all parties involved, particularly for the parents. Although, in the great majority of cases, parents did agree with the interventions the physicians proposed, there were some cases where the parents opposed them. ${ }^{151}$ The decision-making process about sex assignment in patients with CAH reveals the difficulties of sex change before the 1970s. Different factors were decisive: Social criteria, medical ones such as the status of the external genitals and the possibilities of surgical treatment and psychological factors could all tip the balance. As Eder pointed out, medical interventions

\footnotetext{
${ }^{150}$ Letter from the mother of Nils* to Dr med R. Illig, Children's Hospital Zurich, 18 November 1957, patient record, StAZH, 741.10984. Ruth Illig (1924-2017) came in 1956 to Zurich and became a senior physician under Prader.

${ }^{151}$ A.E. Patient record, StAZH, Z 810.3518.
} 
were based on concepts of health 'that encompass both the social and the biological'. ${ }^{152}$ They pursued the aim of societal integration of the children taking into account the definition of health as proposed by the WHO in $1947 .{ }^{153}$ As we have seen, this included not just physical health but also psychological health: A precondition for that in their view was a clearly sexed body and a clear gender identity. The treatment goal of the intervention was built on this assumption. But as we have seen, there was no simple answer to the question of 'right' sex assignment, either for medical experts or for the children's parents. Medical authorities such as Andrea Prader exerted a strong influence on the decision-making processes with their authority as medical experts, often in favour of surgical intervention. But they did not decide the medical treatment in a simple top-down manner. They often informed the parents about the medical possibilities, especially in the case of older children. Along with the treatment recommendations in their publications, they usually weighed the advantages and disadvantages of a sex change and were aware of the farreaching consequences of their recommendations for the families. Notwithstanding, the goal was to maintain a 'clear' gender identity with a 'clearly' sexed body.

\section{Conclusion}

We set out to better understand the clinical management of 'intersex' children in Zurich. We note that the concealment of diagnostic details points to a hierarchy of power and that medical intervention was based on medical knowledge, scientific endeavour and a good dose of power relations. The way that parents (and their children) were nudged, pushed and possibly at times almost coerced into certain decisions clearly point to a problematic setting within this particular medical field. Current historiography suggests that this behaviour was not limited to paediatric medicine at the time. Medicine's historical record reveals problematic, challenging situations rather than the image of a demigod in white. This has been our guiding understanding of history: to show difficulties, to understand complex situations and to reveal a history of medicine in the realities of life.

The field itself was not stable. Emerging diagnostic skills in a changing landscape of increasingly important chronic diseases reveals a group of experts operating under a lot of uncertainty. One of the challenges for medical practice has always been to conceptualise medicine as a science of decisionmaking under uncertainty. Seen from today's perspective, quite a few of the children could simply have been left alone. Social norms at the time were strong though, and we found ample confirmation that the polar gender model of a child being either a boy or a girl was not contested by the medical personnel even if Prader sometimes hinted at just that. The problem is that with such fluid diagnostic categories, syndromes or individual development, situations turned into 'factual' diseases because of the heteronormative sex-gender model. In other words, we see the field as an arena in which social norms carried an enormous weight as justification for medical procedures. It has long been said that diseases as well as syndromes are social constructs in the sense that society gives a name to them and allows medicine to treat patients for them. This field offers excellent empirical material for this notion. But it is not just medicine that has to answer for this: It must have been incredibly difficult for a child to grow up with a nonstandard body. Our study confirms, however, that medicine was more interested in adjusting bodies and therefore hiding biological difference than in educating the public, the parents and the children about the differences in the physical development of children. Our material thus confirms what other authors have argued: That medicine mobilised its arsenal of surgery, drug treatment, psychiatry and more to make sure that the sex-gender world remained in a binary logic. Doctors such as Prader had options, and they chose not to pursue some of those options. But our research also reveals that in the vast majority of cases, the children's families agreed with the doctors. For the families, as much as for Prader and his colleagues, a child needed to have a recognisable sex. The concerns of families were important to the medical personnel, and often treatment was triggered by parents deeply concerned about the physical

\footnotetext{
${ }^{152}$ Eder, op. cit. (note 9), 608.

${ }^{153}$ Eder, op. cit. (note 13 ).
} 
development of their child. Interaction between the doctors and the parents were very common in our case files, and they ranged from active parents demanding intervention to parents resisting everything the doctors mobilised in support of a planned intervention. The history of chronic diseases leads us to another conclusion: That parents were necessary elements of the medical care. Who else would have reported on medication, organised regular urine samples or reported on general medical concerns? It seems to us that the parents were not just there to discuss and interact with doctors, but also as carers for the children. In other words, parents maintained a dual role in this environment. Hence, on the basis of our research, we propose to fundamentally rethink the role of the family in debates about the medical treatment of 'intersex' children. The children themselves, however, remained largely silent. Sometimes, direct communication between child and doctor started in their teenage years, but for the majority of cases, the children only started voicing their opinion retrospectively. One trigger for patients seeking direct communication with the Kispi was when parents did not or would not provide enough answers. So even from the point of view of the children, the role of the parents was a complex one. In some cases, after full disclosure by Prader or one of his colleagues, the grown-up children refused further treatment - and who is to blame them after numerous surgical interventions, long-term cortisone injections and many other interventions. It is not the task of this article to engage with longer-term memories of treatment experiences, but it is noteworthy that medicine, in our time period, was largely free from ethical or political regulation, and it shows in the fact that children and their hopes, fears and opinions were largely ignored. It is for another paper to explain how this gradually changed, but paediatric medicine has often encountered the fundamental challenge of how to take into account children's voices in complex medical situations.

The field was also one of intense scientific and medical debate. This article has mentioned the shifting disease categories and diagnostic names a number of times. For Prader and his team, medicine involved the care of patients, the research dimension and a teaching role. It is sometimes impossible to discern which role was responsible for which activity. It is clear that the reach of the pharmaceutical industry was considerable. It influenced decisionmaking, but it also facilitated new clinical management strategies for new problems. They supplied free drugs and they funded research posts to increase capacity at the Kispi. The role of Swiss health insurance, hospital funding and general social policy was not considered for this article. Financial aspects did not regularly appear in the patient files, and it remains an open question whether such influences existed in 'intersex' management. Prader's work brought huge scientific prestige to Zurich. His visit to the United States and his contact with the leading U.S. endocrinologist, Lawson Wilkins, made Prader a medical scientist of international calibre. All this leads us to conclude that the Swiss story of 'intersex' management should not be studied through the lens of the U.S. model. The field of 'intersex' developed in many places more or less at the same time, one of the drivers in our time period was the Kispi in Zurich. In our time period, 'intersex' was a growing field due to new scientific procedures leading to new diagnostic categories, while drugs and surgery developed new forms of interventions. While the overall number of children remained fairly small, as a new field of chronic disease and birth defect research, the field of 'intersex' became a viable driver of the science-based, internationally connected field of paediatrics and continues to influence current debate on decision-making as well as children's and human's rights in medicine.

Acknowledgements. We thank Sandra Eder and the readers of Medical History for valuable suggestions. We gratefully acknowledge research assistance from Laura Bitterli, Jacqueline Martinelli, Livia Merz and Verena Schönbucher. We also thank the Cantonal State archive of Zurich (Staatsarchiv Zürich) and the company archive of the Swiss pharmaceutical company Novartis for supporting our research.

Funding. The research for this article was made possible by a grant from the Swiss Science Foundation \#105311_169575.

Cite this article: Janett M, Althaus A, Hulverscheidt M, Gobet R, Streuli J, Condrau F (2021). Doctors, families and the industry in the clinic: the management of 'intersex' children in Swiss paediatric medicine (1945-1970). Medical History 65: 286-305, https://doi.org/10.1017/mdh.2021.17 